\title{
Split-Hand/Foot Malformation Type 5
}

National Cancer Institute

\section{Source}

National Cancer Institute. Split-Hand/Foot Malformation Type 5. NCI Thesaurus. Code C75002.

Split-hand/foot malformation mapped to chromosome 2 q31. 